\title{
Use of ice cores from glaciers with melting for reconstructing mean summer temperature variations
}

\author{
Fumio NAKAZAWA, ${ }^{1}$ Koji FUJITA ${ }^{2}$ \\ ${ }^{1}$ Department of Environmental Sciences, Faculty of Science, Shinshu University, Asahi 3-1-1, Matsumoto 390-8621, Japan \\ E-mail: nakazawa@shinshu-u.ac.jp \\ ${ }^{2}$ Graduate School of Environmental Studies, Nagoya University, Nagoya 464-8601, Japan
}

\begin{abstract}
This study examines a new method for reconstructing mean summer temperature variations by using an ice core from a wet-snow zone on a summer-accumulation-type glacier. In July 2001, a $25.1 \mathrm{~m}$ deep ice core was recovered from the accumulation area of Sofiyskiy glacier $\left(49^{\circ} 47^{\prime} \mathrm{N}, 87^{\circ} 43^{\prime} \mathrm{E}\right.$; $3435 \mathrm{~m}$ a.s.l.), located in the southern Chuyskiy range of the Russian Altai mountains, and a $4.5 \mathrm{~m}$ deep pit was excavated about $50 \mathrm{~m}$ northwest of the drill site. The observation site has a positive balance even during summer when melting occurs. The summer balance for each year from 1990 to 2000 was estimated from Pinaceae and Artemisia pollen peaks in these samples. Pinaceae pollen marks spring, whereas Artemisia pollen marks autumn. Moreover, meltwater intrusion did not reach the previous year's accumulation. Thus, the ice between these pollen peaks in the same year was used to estimate a summer balance. The reconstructed summer balance variations were negatively correlated with mean summer temperature variations $(r=-0.72, P<0.05)$. This study shows that, for summer-accumulationtype glaciers such as Sofiyskiy glacier, the most important climate factor controlling the glacier's surface mass balance is mean summer temperature. Therefore, the summer layer thickness in an ice core can be used as a proxy for reconstructing mean summer temperature variations.
\end{abstract}

\section{INTRODUCTION}

Ice cores from mountain glaciers in mid- and low latitudes, although covering shorter timescales, allow for high-resolution analysis due to the high snow accumulation rate as shown by Thompson and others (1984, 1985, 1988), Liu and others (1998, 2005), Fujita and others (2004) and Reese and Liu (2005). Recent studies of pits and an ice core in Russia's Altai mountains demonstrated the potential to separate several seasonal layers using different pollen taxa in the samples (Nakazawa and others, 2004, 2005). This method is suitable for glaciers in mid- and low latitudes, rather than polar ice sheets and glaciers, because they are situated close to vegetation sources (usually within a few tens of kilometers). Thus, pollen analysis in the glaciers is expected to complement chemical, biological and physical analysis with seasonal resolution. Moreover, these analyses should be useful for understanding past climates in mountain regions of mid- and low latitudes where meteorological data are often limited.

Concerning the reconstruction of past temperatures using an ice core, studies from Greenland and Antarctica have produced many results by using the correlation between oxygen and hydrogen isotope ratios $\left(\delta^{18} \mathrm{O}\right.$ and $\left.\delta \mathrm{D}\right)$ and temperature (e.g. Jouzel and others, 1987; Johnsen and others, 1992; Dansgaard and others, 1993; Petit and others, 1999). In contrast, few studies have succeeded in reconstructing paleotemperature using ice cores from mid- and low-latitude glaciers (e.g. Thompson and others, 1989, 1995, 2000). This is in part because isotopic ratios have been suggested to be more dependent on the amount of precipitation than on temperature (Wushiki, 1977; AraguásAraguás and others, 1998; Johnson and Ingram, 2004), and they may be altered by summer melting of glaciers.

In this paper, we examine the potential for reconstructing mean summer temperature variations using summer layer thickness in a pit and an ice core from a wet-snow zone on a summer-accumulation-type glacier. Here the accumulation and ablation seasons coincide in summer, whereas winters are generally too cold and/or too dry to add significant massbalance variability. Therefore, accumulation areas of the glaciers often have a positive balance even during summer when melting occurs.

On the other hand, the climate sensitivity of a glacier is usually derived from the glacier's surface mass balance, which depends on climate conditions such as annual temperature and precipitation. For summer-accumulationtype glaciers, it has been argued that the most important climate factor driving this behavior is mean summer temperature (Ageta and Higuchi, 1984; Fujita and Ageta, 2000; De Smedt and Pattyn, 2003). This implies that fluctuations in the mass balance of these glaciers are mainly controlled by the amount of melting rather than the annual amount of precipitation. Thus, if the summer layers in an ice core from summer-accumulation-type glaciers can be distinguished and can be regarded as an indicator of summer balance, the annual fluctuations in the balance may be a good marker of the annual fluctuations in mean summer temperature.

\section{STUDY AREA AND METHODS}

Sofiyskiy glacier $\left(49^{\circ} 47^{\prime} \mathrm{N}, 87^{\circ} 43^{\prime} \mathrm{E}\right)$, located in Akkol valley, is one of the major glaciers in the central part of the south Chuyskiy range within the Russian Altai mountains, situated in the border region between Russia and Mongolia (Fig. 1). In July 2001, a 25.1 m deep ice core was recovered on the accumulation area of Sofiyskiy glacier (3435 ma.s.I.), and a $4.5 \mathrm{~m}$ deep pit was excavated about $50 \mathrm{~m}$ northwest of the drill site (Fig. 2). Fujii and others (2002) found that surface melting occurs during the summer season at the drill site. Each borehole temperature profile measured in July 2000 and July 2001 ranged from $0^{\circ} \mathrm{C}$ at the 
$87^{\circ} 30^{\prime} \mathrm{E}$

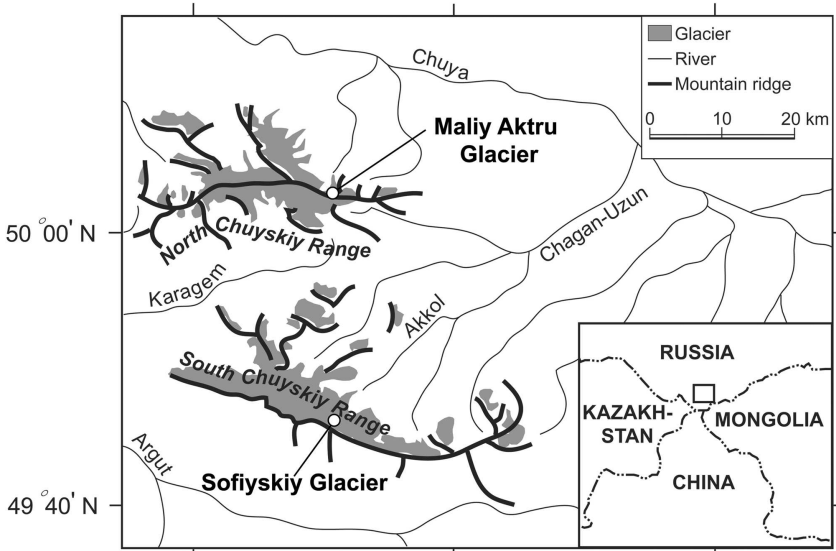

Fig. 1. Location of the north and south Chuyskiy range of the Russian Altai mountains.

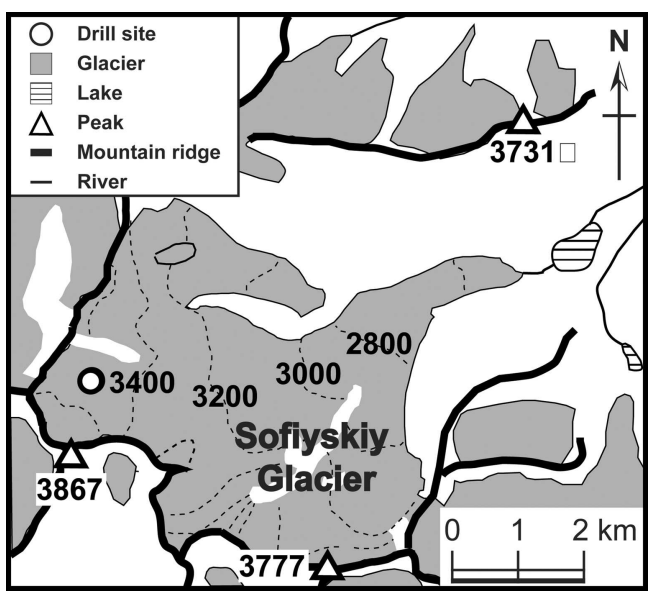

Fig. 2. Contour map of Sofiyskiy glacier. surface to minimum temperatures of $-0.1^{\circ} \mathrm{C}$ and $-0.3^{\circ} \mathrm{C}$ at $10 \mathrm{~m}$ depth for the boreholes in 2000 and 2001, respectively. The temperature gradually increased below $10 \mathrm{~m}$ depth and warmed to $0.0^{\circ} \mathrm{C}$ again below about $16 \mathrm{~m}$ depth. Hence the site is located in the so-called wet-snow zone. Annual snow accumulation on the drill site is often $>1 \mathrm{~m}$, as shown by Nakazawa and others (2004).

The core samples were cut at intervals of about $20 \mathrm{~cm}$, and pit samples were obtained every $10 \mathrm{~cm}$. We analyzed all pit samples and core samples down to $18.60 \mathrm{~m}$ depth for pollen concentrations and oxygen isotope ratios $\left(\delta^{18} \mathrm{O}\right)$. For the pollen analysis, $10 \mathrm{~mL}$ of each water sample were filtered through hydrophilic polytetrafluoroethene (PTFE) membrane filters with a pore size of $0.2 \mu \mathrm{m}$, and pollen grains on the filters were counted by viewing them through a microscope. To keep the process simple and to prevent pollen loss, no chemical treatment and no centrifuge operation was used on the samples. Total pollen counts in the samples ranged from 0 to 379 grains.

Mass-balance observations from 1980 to 2001 were recorded from three glaciers (No. 125 glacier $\left(50^{\circ} 06^{\prime} \mathrm{N}\right.$, $\left.87^{\circ} 42^{\prime} \mathrm{E}\right)$, Maliy Aktru glacier $\left(50^{\circ} 05^{\prime} \mathrm{N}, 87^{\circ} 45^{\prime} \mathrm{E}\right)$ and Leviy Aktru glacier $\left(50^{\circ} 05^{\prime} \mathrm{N}, 87^{\circ} 43^{\prime} \mathrm{E}\right)$ ) within the same basin in the north Chuyskiy range, some $30 \mathrm{~km}$ to the north of Sofiyskiy glacier. Only the mean annual data of the observations are available in Haeberli and others (2003). Long- term records of monthly temperature and precipitation were collected during 1972-94 at Aktru meteorological station, located at the foot of Maliy Aktru glacier (2150 ma.s.l.). We also used monthly temperature and precipitation since 1990 for Akkem meteorological station $(2050 \mathrm{~m})$, located at the foot of Belukha mountain and $80 \mathrm{~km}$ west of Sofiyskiy glacier, for data analysis.

\section{RESULTS AND DISCUSSION}

The pollen analyses of the pit and core samples showed that the most abundant pollen were Pinaceae (Pinus, Picea and Abies) and Artemisia pollen. Figure $3 \mathrm{a}$ and $\mathrm{b}$ show Pinaceae and Artemisia pollen concentrations both in the pit and in the firn core. The concentrations in the upper parts at 0 $4.5 \mathrm{~m}$ depth are plotted from the pit data. The core consists of firn with interbedded ice layers down to $18.25 \mathrm{~m}$ depth and then only ice below that depth. The detailed stratigraphy of the core and the pit is discussed in Kameda and others (2004) and Nakazawa and others (2004), respectively. According to a study on plants in Russia's Altai region (Luchik, 1970), the flowering of Pinaceae starts from May. Luchik did not report the flowering season of Artemisia. However, Artemisia typically flowers in early autumn in Asia (Satake and others, 1981; Polunin and Stainton, 1984; Qiao, 2004). Thus, we assumed that the Artemisia's flowering season near the glacier is in late August and early September.

The assumption regarding Artemisia's flowering season is probably realistic. The pollen dispersal season for a given species coincides with its flowering season, which depends on the locality including the altitude, with some variation in dates of pollen dispersal depending on the individual plant. Therefore, the pollen season for a given species typically lasts a few months, with each pollen type having the peak month. However, the magnitude of pollen dispersal changes from year to year. On the other hand, the temperature records between 1990 and 2000 at Akkem meteorological station show that mean monthly temperatures in August, September and October are 8.1, 3.3 and $-3.0^{\circ} \mathrm{C}$, respectively. Akkol valley, whose floor lies at $2300 \mathrm{~m}$ a.s.l. and which is the nearest source of Artemisia pollen for Sofiyskiy glacier, should be covered in snow by October. In addition, the Artemisia-rich layer for 2001 had not yet appeared in the pit samples collected on 9 July, a mid-summer's day. Thus, the season of maximum dispersal of Artemisia pollen near the glacier should be in late August to early September.

The pollen analysis allows us to estimate the summer layers as shown in our previous study (Nakazawa and others, 2004). The pollen profiles show the alternating Pinaceaeand Artemisia-rich layers. The dating of the pit and firn core is conducted by counting alternations of the pollen strata, and annual boundaries between 1990 and 2001 on the plots are marked from Pinaceae peaks. Uetake and others (2006) studied the influence of particle transport from snowmelting using different sizes of snow algae in our study core and pit samples. Snow algae grow on glaciers in the summer and then form algal peaks in snow (Yoshimura and others, 2000). They found that algae smaller than $7.5 \mu \mathrm{m}$ showed ambiguous peaks in the pit and core, and concluded that small algae may have been transported down-core by meltwater. In contrast, algae larger than $7.5 \mu \mathrm{m}$ remained the peaks. The sizes of Artemisia and Pinaceae pollen are 20 


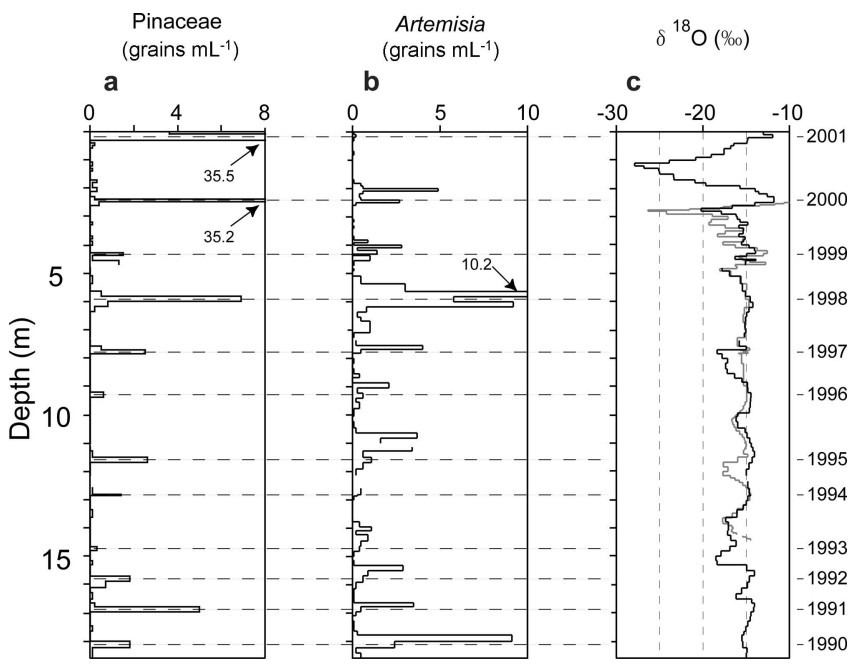

Fig. 3. Vertical profiles from the pit and ice-core samples on Sofiyskiy glacier: (a) Pinaceae pollen concentration measured in July 2001; (b) Artemisia pollen concentration measured in July 2001; and (c) oxygen isotope ratios $\left(\delta^{18} \mathrm{O}\right)$ measured in July 2000 (shaded line) and July 2001 (black line). The dashed lines with labels indicate annual boundaries estimated from Pinaceae pollen peaks. The depths of the $\delta^{18} \mathrm{O}$ profiles in 2000 are adjusted to the depth scale in 2001 so that the maximum and minimum values in each year have the same depths. For the 2001 data, the upper parts down to $4.5 \mathrm{~m}$ depth came from the pit samples, while the lower parts are from the core samples.

and $50-130 \mu \mathrm{m}$, respectively. Therefore, pollen transport to the lower layers would probably have been insignificant. Moreover, Vareschi (1937) reported that pollen percolation through the snow layers by meltwater did not occur. On the other hand, the Artemisia-rich layer for 1998 covers a wide region. This may be due to extensive pollen dispersal since the mean summer temperature in 1998 was the highest in the period 1990-2000 (Fig. 4). The high temperature may have enhanced its growth, leading to high pollen production, although other factors such as the efficiency of transport mechanisms may also influence the magnitude. Also, some Artemisia-rich layers have two peaks, the smaller one below and the larger one above. The possible interpretation of the result is that the smaller peak was formed by pollen concentration due to meltwater runoff in summer and the larger peak was formed at the peak of the pollen season. Since all Artemisia peaks in the pit and core profiles are above the Pinaceae peaks (about 0.90-0.10m), the firn between Pinaceae and Artemisia pollen peaks from the same year can be considered to be the summer layer. This indicates that the observation site has a positive balance even during summer when melting occurs.

Our reconstructed summer layers determined from pollen analysis can be regarded as the summer balances. Figure 3c examines alterations of $\delta^{18} \mathrm{O}$ by meltwater process, such as meltwater percolation and subsequent refreezing lower down. The black line is $\delta^{18} \mathrm{O}$ measured in July 2001, whereas the shaded line shows the same site in July 2000 (Kameda and others, 2003). For the 2001 data, the upper parts down to $4.5 \mathrm{~m}$ depth are based on the pit samples, while the lower parts are from the core samples. The depths of the $\delta^{18} \mathrm{O}$ profiles in 2000 are adjusted to the depth scale in 2001 so that the maximum and minimum values in each year have the same depths. The maximum peak in the 2000

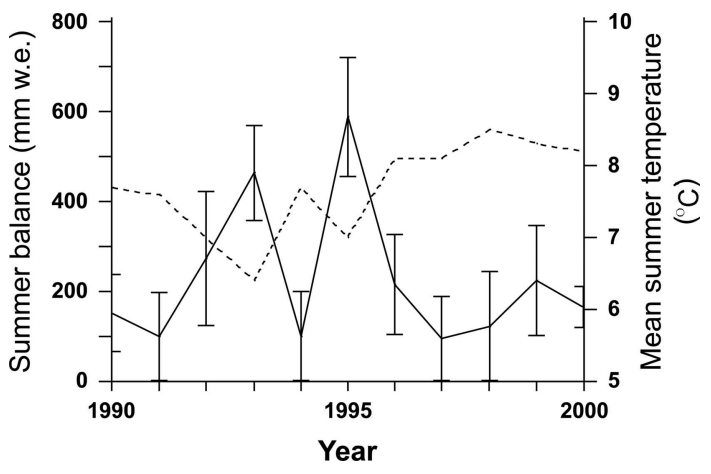

Fig. 4. Reconstructed summer balance (solid line) and mean summer temperatures (May-August) (dashed line) at Akkem. Error bars calculated from the ranges of ice cutting.

summer (2.5 m depth) and the minimum peak in the 1999/ 2000 winter (2.8 $\mathrm{m}$ depth) were lower in July 2001 than in July 2000. However, both profiles show similar maximum and minimum values in the deeper layers. If frequent percolation and refreezing of meltwater had occurred in the layers, the maximum (minimum) value of $\delta^{18} \mathrm{O}$ in the 2001 profile should have changed into the lower (higher) value than that in the 2000 profile. Also, the change of a $\delta^{18} \mathrm{O}$ value would be seen even with the exchange of the same amount of inflow and discharge water. However, the differences between the peak values in both profiles are $<1 \%$ in almost all cases. In particular, the maximum values of both samples that indicate summer layers are likely to have been well preserved over time. Therefore, meltwater percolation within the firn is probably insignificant, although the firn temperature in the uppermost $8 \mathrm{~m}$ and the lower part from $16 \mathrm{~m}$ depth rose to $0^{\circ} \mathrm{C}$ during summer. Also, the firn temperature in the region of 8-16 m depth was a negative value as of the mid-summer. In contrast, only summer surface meltwater seems to percolate into the surface snow layer and thus alter the seasonal variation in $\delta^{18} \mathrm{O}$ of the current year by the end of the melt season. The meltwater should affect not only the summer layer but also spring and winter layers that should be from a few to a few tens of centimeters below the early-summer level. However, the water influencing the spring and winter layers is treated as the discharged water for the calculation of summer balance. Also, the water refreezing in the summer layer should be counted as the internal accumulation. At the same time, a high accumulation rate over $1 \mathrm{~m}$ on Sofiyskiy glacier may prevent the meltwater from percolating into the previous summer layer. All of this amounts to saying that the meltwater is unlikely to alter the summer balance during 1990-2000.

The variations in the summer balance during 1990-2000 show a good negative correlation with the changes in the mean summer temperature $(r=-0.72, P<0.05)$ at Akkem meteorological station, but a distinct link with the annual precipitation $(r=0.41, P>0.05)$ or the summer precipitation $(r=0.29 P>0.05)$ is lacking (Fig. 4). The summer period May-August is used here for the correlation analysis because it corresponds to the difference of high season between these two types of pollen in the Russian Altai region.

The good negative correlation seems to result from a feature of summer-accumulation-type glaciers. We found that the mean annual mass balance of three glaciers 


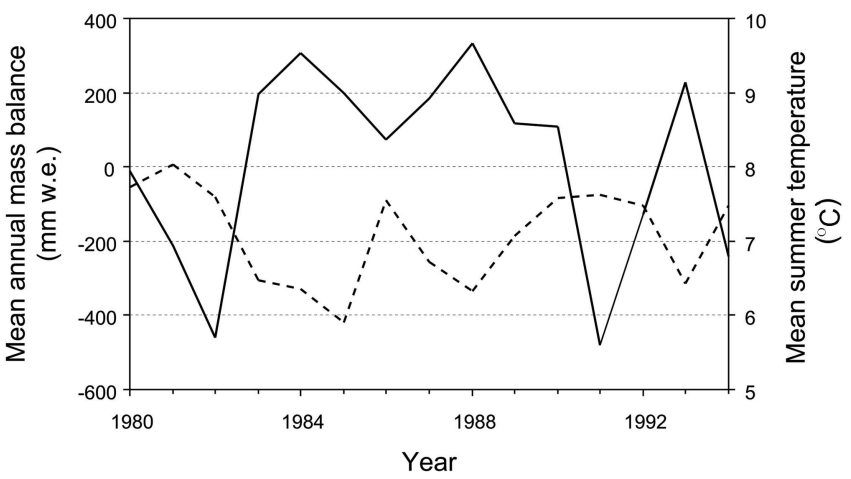

Fig. 5. Mean annual mass balance of three glaciers (No. 125, Maliy Aktru and Leviy Aktru glaciers) in the north Chuyskiy range (solid line), and mean summer temperature (May-August) at Aktru meteorological station (dashed line).

(No. 125, Maliy Aktru and Leviy Aktru glaciers) in the north Chuyskiy range shows a good negative correlation with the mean summer temperature from May to August at the Aktru meteorological station (Fig. 5). The correlation coefficient is $-0.75(P<0.001)$, whereas the annual precipitation $(r=0.33, P>0.05)$, mean annual temperature $(r=0.44$, $P>0.05)$ or summer precipitation $(r=0.09, P>0.05)$ shows an unclear correlation. A similar negative correlation between Aktru's mean summer temperature and Maliy Aktru glacier's annual mass-balance variation was also reported by De Smedt and Pattyn (2003). Hence, this feature may be applicable to many summer-accumulation-type glaciers in Russia's Altai mountains. In particular, Sofiyskiy glacier lies only $30 \mathrm{~km}$ from the basin, making it likely that the glacier's annual mass-balance variation is sensitive to summer temperature. In addition, it seems reasonable to suppose that the summer temperature directly influences the summer mass balance because the melting occurs only during summer. Thus, it can be seen that our summer balance data show a good negative correlation with the mean summer temperature.

\section{CONCLUSION}

This study examines a new method for reconstructing mean summer temperature variations using an ice core from a wet-snow zone on a summer-accumulation-type glacier. The summer balance variations reconstructed using difference in the timing of dispersal for two different types of pollen showed a good negative correlation $(r=-0.72, P<0.05)$ with mean summer temperature variations. Thus, this method appears to be useful for reconstructing mean summer temperature variations for glaciers with significant melting. There may be occasional uncertainties of annual summer balance due to alteration by melting in subsequent years. However, when viewed within a long-term perspective, depending on the degree of meltwater penetration (e.g. the summer balance data are smoothed by some sort of running mean), this method may prove useful. Moreover, it seems to be more applicable to the cold glaciers in Tibet and the Himalaya of central Asia because ice cores in these glaciers can be obtained from the percolation zone, and meltwater should not disturb the layers deposited in previous years. Thus, it should be easier to consider the summer layer as the summer balance. These conclusions are based on only one set of ice-core data. Therefore, additional tests using other ice cores are necessary to advance the utility of this method. The mid- and low-latitude glaciers where significant melting occurs have seldom had ice-core study performed on them to date. Therefore, the separation of seasonal layers using different pollen taxa in such glaciers may explain the seasonal climate fluctuations in the mountain regions in the past such as the mean summer temperature.

\section{ACKNOWLEDGEMENTS}

We thank the members of the Japan-Russia Joint Glaciological Research team on Sofiyskiy glacier in 2000 and 2001 for generous assistance with this research. Thanks are also due to $\mathrm{V}$. Aizen for providing the meteorological data for Aktru and Akkem meteorological stations, and to two reviewers for valuable comments and criticisms. This research was supported by the Oasis Project (Historical evolution of adaptability in an oasis region to water resource changes), promoted by the Research Institute for Humanity and Nature, Kyoto, Japan.

\section{REFERENCES}

Ageta, Y. and K. Higuchi. 1984. Estimation of mass balance components of a summer-accumulation type glacier in the Nepal Himalaya. Geogr. Ann., 66A(3), 249-255.

Araguás-Araguás, L., K. Froelich and K. Rozanski. 1998. Stable isotope composition of precipitation over southeast Asia. J. Geophys. Res., 103(D22), 28,721-28,742.

Dansgaard, W. and 10 others. 1993. Evidence for general instability of past climate from a 250-kyr ice-core record. Nature, 364(6434), 218-220.

De Smedt, B. and F. Pattyn. 2003. Numerical modelling of historical front variations and dynamic response of Sofiyskiy glacier, Altai mountains, Russia. Ann. Glaciol., 37, 143-149.

Fujii, Y. and 10 others. 2002. Outline of Japan-Russia joint glaciological research on Sofiyskiy Glacier, Russian Altai Mountains in 2000 and 2001. Bull. Glaciol. Res., 19, 53-58.

Fujita, K. and Y. Ageta. 2000. Effect of summer accumulation on glacier mass balance on the Tibetan Plateau revealed by massbalance model. J. Glaciol., 46(153), 244-252.

Fujita, K., N. Takeuchi, V. Aizen and S. Nikitin. 2004. Glaciological observations on the plateau of Belukha Glacier in the Altai Mountains, Russia from 2001 to 2003. Bull. Glaciol. Res., 21, 57-64.

Haeberli, W., R. Frauenfelder, M. Hoelzle and M. Zemp, eds. 2003. Glacier Mass Balance Bulletin No. 7 (2000-2001). Zürich, World Glacier Monitoring Service.

Johnsen, S.J. and 9 others. 1992. Irregular glacial interstadials recorded in a new Greenland ice core. Nature, 359(6393), 311-313.

Johnson, K.R. and B.L. Ingram. 2004. Spatial and temporal variability in the stable isotope systematics of modern precipitation in China: implications for paleoclimate reconstructions. Earth Planet. Sci. Lett., 220(3-4), 365-377.

Jouzel, J. and 6 others. 1987. Vostok ice core: a continuous isotope temperature record over the last climatic cycle (160,000 years). Nature, 329(6138), 403-408.

Kameda, T. and 6 others. 2003. Seasonality of isotopic and chemical species and biomass burning signals remaining in wet snow in the accumulation area of Sofiyskiy Glacier, Russian Altai Mountains. Polar Meteorol. Glaciol., 17, 15-24.

Kameda, T. and 9 others. 2004. Stratigraphy and ice grains of a $25.3 \mathrm{~m}$ ice core from Sofiyskiy Glacier, Russian Altai Mountains. Bull. Glaciol. Res., 21, 65-69. 
Liu, K.B., Z. Yao and L.G. Thompson. 1998. A pollen record of Holocene climatic changes from the Dunde ice cap, QinghaiTibetan Plateau. Geology (Boulder), 26(2), 135-138.

Liu, K.B., C.A. Reese and L.G. Thompson. 2005. Ice-core pollen record of climatic changes in the central Andes during the last 400 years. Quat. Res., 64, 272-278.

Luchik, Z.I. 1970. [Introduction to trees and shrubs in Altai territory.] Moscow, Kolos. [In Russian.]

Nakazawa, F. and 8 others. 2004. Application of pollen analysis to dating of ice cores from lower-latitude glaciers. J. Geophys. Res., 109(F4), 4001. (10.1029/2004JF000125.)

Nakazawa, F. and 6 others. 2005. Dating of seasonal snow/firn accumulation layers using pollen analysis. J. Glaciol., 51(174), 483-490.

Petit, J.R. and 18 others. 1999. Climate and atmospheric history of the past 420,000 years from the Vostok ice core, Antarctica. Nature, 399(6735), 429-436.

Polunin, O. and A. Stainton. 1984. Flowers of the Himalayas. New Delhi, Oxford University Press.

Qiao, B. 2004. Color atlas of air-borne pollens and plants in China. Beijing, Peking Union Medical College Press. [In Chinese.]

Reese, C.A. and K.B. Liu. 2005. Inter-annual variability in pollen dispersal and deposition on the tropical Quelccaya Ice Cap. Professional Geographer, 57(2), 185-197.

Satake, Y., J. Ohwi, S. Kitamura, S. Watari and T. Tominari. 1981. Wild flowers of Japan: herbaceous plants including dwarf subshrubus. Tokyo, Heibon-sha. [In Japanese.]

Thompson, L.G., E. Mosley-Thompson and B.M. Arnao. 1984. Major El Niño/Southern Oscillation events recorded in the stratigraphy of the tropical Quelccaya Ice Cap. Science, 226(4670), 50-52.
Thompson, L.G., E. Mosley-Thompson, J.F. Bolzan and B.R. Koci. 1985. A 1500-year record of tropical precipitation in ice cores from the Quelccaya ice cap, Peru. Science, 229(4717), 971-973.

Thompson, L.G., X. Wu, E. Mosley-Thompson and Z. Xie. 1988. Climatic records from the Dunde ice cap, China. Ann. Glaciol., 10, 178-182.

Thompson, L.G. and 9 others. 1989. Holocene-Late Wisconsin Pleistocene climatic ice core records from Qinghai-Tibetan Plateau. Science, 246(4929), 474-477.

Thompson, L.G. and 7 others. 1995. Late glacial stage and Holocene tropical ice core records from Huascarán, Peru. Science, 269(5220), 46-50.

Thompson, L.G., T. Yao, E. Mosley-Thompson, M.E. Davis, K.A. Henderson and P. Lin. 2000. A high-resolution millennial record of the south Asian monsoon from Himalayan ice cores. Science, 289(5486), 1916-1919.

Uetake, J. and 7 others. 2006. Biological ice-core analysis of Sofiyskiy glacier in the Russian Altai. Ann. Glaciol., 43 (see paper in this volume).

Vareschi, V. 1937. Prüfrung der neuen pollenanalytischen Methode der Gletscherforschung an Hand eines Firnprofiles von bekannter Entstehungzeit. Zeitschrift für Gletscherkunde, für Eiszeitforschung und Geschichte des Klimas, 25, 17-35.

Wushiki, H. 1977. Deuterium content in the Himalayan precipitation at Khumbu District, observed in 1974/1975. J. Jpn. Soc. Snow and Ice, Seppyo, 39, 50-56.

Yoshimura, Y., S. Kohshima, N. Takeuchi, K. Seko and K. Fujita. 2000. Himalayan ice-core dating with snow algae. J. Glaciol., 46(153), 335-340. 